\title{
Perupaan dan Sinkronisasi Artefak Percandian Batujaya di Karawang, Jawa Barat dengan Borobudur di Jawa Tengah dan Mon-Dwarawati di Thailand
}

\author{
Nuning Damayanti ${ }^{1}$ Ira Adriati $^{1} \&$ Savitri Putri Ramadina ${ }^{1,2}$ \\ ${ }^{1}$ Fakultas Seni Rupa dan Desain, Institut Teknologi Bandung, \\ Jl. Ganesa No. 10, Bandung, Indonesia \\ ${ }^{2}$ Universitas Widyatama, Jl. Cikutra No. 204 A Bandung, Indonesia \\ E-mail: savitri.putri@widyatama.ac.id
}

\begin{abstract}
Abstrak. Percandian Batujaya adalah sebuah kompleks sisa-sisa percandian Budha kuno yang terletak di Kecamatan Batujaya dan Kecamatan Pakisjaya, Kabupaten Karawang, Provinsi Jawa Barat. Adanya dua fase pembangunan pada Batujaya membuka kemungkinan terhadap interpretasi akan adanya gaya-gaya perupaan yang berbeda pada percandian Batujaya. Berdasarkan hasil penelitian, dapat ditarik kesimpulan bahwa mazhab Budha yang diterapkan pada kompleks percandian Batujaya adalah mazhab Mahayana, dicirikan dengan keberadaan votive tablet dengan perupaan yang menggambarkan sosok-sosok bodhisattva dan Budha. Perbandingan gaya visual dengan artefak-artefak yang berasal dari periode Mon-Dwarawati di wilayah Thailand dan artefak Borobudur di Jawa Tengah menunjukkan bahwa artefak Batujaya cenderung memiliki gaya naturalis yang lebih serupa dengan Dwarawati terutama pada profil wajah dibandingkan gaya stilasi Borobudur yang lebih dekat secara geografis. Terdapat ciri khas pada arca Batujaya yaitu cenderung memiliki bentuk mata yang didistorsi menjadi lebih besar dan terkesan membelalak, serta hidung yang lebar. Kemungkinan hal ini didasari bentuk fisik masyarakat lokal atau pemikiran ideal lokal mengenai fisik yang sempurna.
\end{abstract}

Kata kunci: arca; Batujaya; Budha Mahayana; gaya perupaan; votive tablet.

\begin{abstract}
Batujaya enshrinement complex is a remnant of ancient Buddhist monument, located in Kecamatan Batujaya and Kecamatan Pakisjaya, Karawang, West Java. The two development phases of Batujaya would open the possibility of different interpretations of visual style in Batujaya. Based on these results, it could be concluded that the Buddhist sect worshipped in Batujaya was Mahayana sect, characterized by votive tablets depicting bodhisattva and Budha. Comparison of visual style with the artifacts dating from Mon-Dvaravati period in Thailand region and Borobudur in Central Java indicated that Batujaya artifacts tend to have more naturalistic style similar to Dwarawati primarily onfacial profile compared to Borobudur style that was closer geographically. There are characteristics found in Batujaya statues, namely the tendency of eyes being distorted and gave the impression of bulging, and wide noses. There is
\end{abstract}

Received October $4^{\text {th }}, 2012$, Revised September $27^{\text {th }}, 2013$, Accepted for publication January $16^{\text {th }}, 2014$. Copyright (C) 2014 Published by LPPM ITB, ISSN: 1978-3078, DOI: 10.5614/itbj.vad.2014.6.2.2 
some possibility that it was based on the physical feature of local people or the local beliefs of an ideal physique.

Keywords: Batujaya; Mahayana Buddhism; statue; visual style; votive tablet.

\section{$1 \quad$ Pendahuluan}

Kompleks percandian Batujaya adalah sebuah kompleks sisa-sisa percandian Budha kuno yang terletak di Kecamatan Batujaya dan Kecamatan Pakisjaya, Kabupaten Karawang, Provinsi Jawa Barat. Situs Batujaya secara administratif terletak di dua wilayah desa, yaitu Desa Segaran, Kecamatan Batujaya dan Desa Telagajaya, Kecamatan Pakisjaya di Kabupaten Karawang, Jawa Barat. Luas situs Batujaya ini diperkirakan sekitar $5 \mathrm{~km}^{2}$. Situs ini terletak di tengah-tengah daerah persawahan dan sebagian di dekat permukiman penduduk dan tidak berada jauh dari garis pantai utara Jawa Barat (pantai Ujung Karawang), dengan koordinat $06^{\circ} 06^{\prime} 15^{\prime}{ }^{\prime}-06^{\circ} 06^{\prime} 17^{\prime \prime}$ LS dan $107^{\circ} 01^{\prime}-107^{\circ} 09^{\prime}$ BT.

Daerah Batujaya pertama kali disebut dalam buku karangan F. de Haan yang menyebutkan bahwa Batujaya pada tahun 1684 masih berupa daerah rawa. Wilayah ini kemudian diteliti oleh tim arkeologi Fakultas Sastra Universitas Indonesia pada tahun 1984 berdasarkan laporan penduduk tentang penemuan gundukan-gundukan tanah di tengah-tengah sawah yang di dalamnya terdapat susunan bata. Gundukan-gundukan ini oleh penduduk setempat disebut sebagai unur dan dikeramatkan oleh warga sekitar. Dari sedikitnya 20 sisa bangunan bata yang terdapat pada situs Batujaya yang telah diteliti sejak 1985 hingga 2007 (tidak termasuk penemuan-penemuan setelah tahun tersebut), dapat diidentifikasi sedikitnya 16 sisa bangunan candi dan 3 bangunan yang diperkirakan merupakan bangunan profan [1].

Kompleks percandian Batujaya sendiri dibangun dalam dua fase: fase pertama diperkirakan berlangsung antara abad ke-5 dan ke-8 Masehi, sementara fase kedua berkisar antara abad ke-8 hingga ke-10 Masehi [2]. Temuan inskripsi beraksara Pallava atau Pali dan berbahasa Sanskerta berisi kutipan ayat dari kitab Pratityasamutpada sutra menghasilkan interpretasi bahwa percandian Batujaya merupakan percandian yang bercorak Budha Mahayana, dikarenakan Pratityasamutpada sutra yang merupakan kitab penting dalam ajaran Budha Mahayana [1].

Bentuk utuh bangunan-bangunan candi yang ditemukan pada situs Batujaya sulit direkonstruksi secara pasti. Meskipun demikian, berdasarkan bukti-bukti pendukung berupa peninggalan artefak seperti epigrafi, votive tablet (simbol atau ikon Budha berukuran kecil yang umumnya dicetak pada medium tanah liat sebagai persembahan), dan arca-arca dapat dipastikan bahwa Batujaya 
merupakan percandian agama Budha. Peninggalan arkeologi berupa sisa bangunan yang ditemukan di situs Batujaya yang berasal dari masa HinduBudha adalah bangunan candi, bangunan profan, dan tembok keliling [2].

Kajian arsitektural pada kompleks percandian Batujaya juga menunjukkan adanya kesamaan gaya perupaan dengan India utara, khususnya daerah Nalanda yang dipengaruhi gaya Gandhara. Pengaruh Budha Mahayana dan kesenian Nalanda tersebut diduga masuk melalui pengaruh kerajaan Sriwijaya yang berpusat di Sumatra dan sedang melakukan ekspansi kerajaan, salah satunya adalah usaha menaklukkan Bhumijawa, termasuk Tarumanagara [1].

Wujud budaya fisik adalah salah satu dari empat wujud kebudayaan yang diajukan oleh Kontjaraningrat, yaitu: (1) artefak atau benda-benda fisik; (2) sistem tingkah laku dan tindakan yang berpola; (3) sistem gagasan; (4) dan sistem ideologi atau nilai. Contoh wujud budaya fisik adalah bangunan buatan manusia seperti Candi Borobudur atau benda pakai seperti gerabah, piring, dan gelas. Sebutan khusus bagi kebudayaan dalam wujud konkret ini adalah "kebudayaan fisik" karena ia dapat diindrakan (disentuh, dirasakan, dilihat, difoto, dan sebagainya) [3]. Artefak budaya fisik bergantung pada latar belakang terwujudnya artefak tersebut serta nilai dan makna dari proses perwujudannya.

Sebagai obyek budaya fisik yang bersifat postfactum (telah ada sebelumnya), artefak percandian Batujaya memiliki karakteristik yang mencerminkan latar kondisi zaman serta latar belakang sosial masyarakat pendukung budaya tersebut. Kondisi dan peristiwa yang terjadi pada masa produksi artefak dapat ditelaah secara sinkronik untuk kemudian diperoleh aspek-aspek yang mempengaruhi nilai dan visualisasi obyek, sementara komparasi gaya dan kecenderungan visual pada artefak percandian Batujaya dilakukan secara diakronik. Dua fase pembangunan kompleks percandian Batujaya sendiri membuka kemungkinan terhadap interpretasi akan adanya gaya-gaya perupaan yang berbeda atau justru berevolusi secara diakronis pada periode antara kedua fase tersebut. Tetapi sejauh ini belum ada kajian yang menyeluruh mengenai perupaan artefak-artefak tersebut, karenanya penelitian ini diharapkan mampu menghasilkan data yang dapat memperluas khazanah seni rupa Indonesia, khususnya seni rupa masa Budha awal di daerah Jawa Barat.

\section{Wujud Rupa Artefak Percandian Batujaya}

Artefak-artefak kompleks percandian Batujaya yang akan ditelaah pada penelitian ini umumnya dapat dibagi menjadi tiga kategori: fragmen arca stuko, fragmen arca terakota, dan votive tablet. Gambar-gambar artefak yang digunakan pada penelitian ini bersumber dari literatur penelitian yang 
Tabel 1 Sampel Perupaan Fragmen Arca Manusia Batujaya.

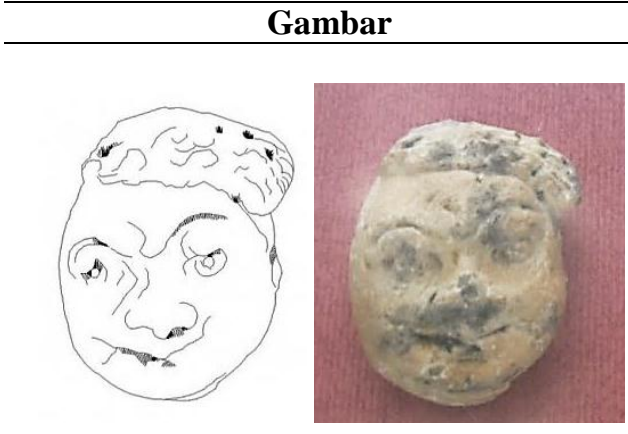

[4]

Keterangan

- Arca kepala manusia dari bahan stuko.

- Ditemukan di situs Candi Telagajaya I-C [1].

- Wujud rupa: bentuk wajah bulat, hidung besar dan pesek, mata seakan melotot, bibir terkatup. Memakai tutup kepala atau rambut pendek yang ikal.

- Gaya perupaan naturalis-stilasi, terutama pada bagian mata.

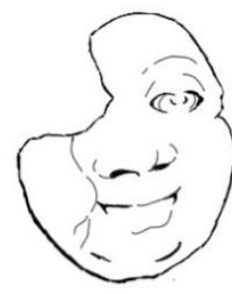

[4]

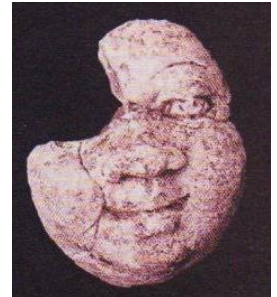

[1]

- Arca kepala manusia dari bahan stuko.

- Ditemukan di situs Candi Telagajaya I-C [1].

- Wujud rupa: bentuk wajah bulat, hidung besar dan pesek, mata besar dengan kelopak setengah tertutup, bibir terkatup. Tidak ada perupaan rambut atau tutup kepala.

- Gaya perupaan naturalistik.

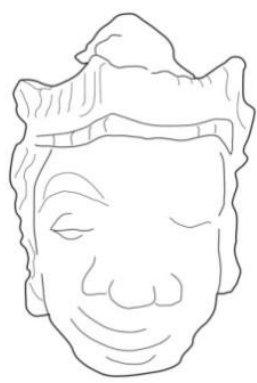

[4]

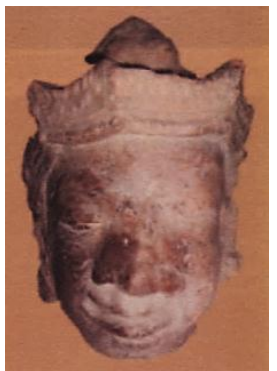

[5]
- Arca kepala manusia dari bahan terakota.

- Wujud rupa: mata setengah terbuka, hidung besar dan pesek, mulut terkatup dan tampak tersenyum, bibir tebal dan lebar. Terdapat bentukan seperti tutup kepala atau mahkota.

- Gaya perupaan naturalis-stilasi dengan perupaan dekoratif pada bagian aksesori kepala; bagian hidung sedikit distorsi. 
Tabel 1 (Lanjutan) Sampel Perupaan Fragmen Arca Hewan Batujaya.

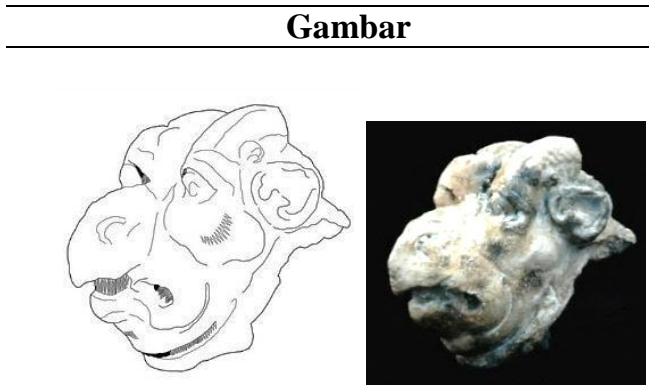

[4]
$[5]$

\section{Keterangan}

- Arca kepala burung dari bahan stuko. Kemungkinan adalah perupaan Garuda.

- Ditemukan di situs Candi Telagajaya I-C [1].

- Wujud rupa: mata terbuka, paruh setengah terbuka.

- Gaya perupaan naturalis-stilasi; profil hewan masih dapat dikenali. Bagian mata sedikit distorsi.

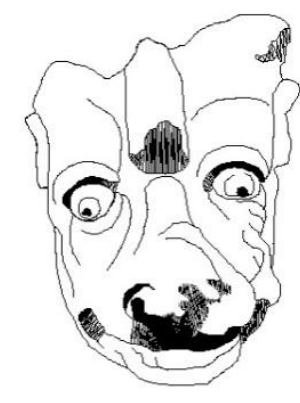

[4]

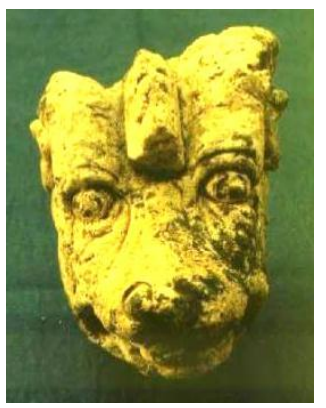

[5]
- Arca kepala hewan dari bahan stuko. Diperkirakan merepresentasikan domba.

- Ditemukan di situs Candi Telagajaya I-C [1].

- Wujud rupa: mata melotot, moncong seperti terkatup atau setengah terbuka.

- Gaya perupaan naturalis-stilasi; profil hewan masih dapat dikenali. Bagian mata sedikit distorsi.

dilakukan oleh Hasan Djafar [1] dan data-data yang dimiliki oleh Pusat Arkeologi Nasional (Tabel 1), dikarenakan data gambar yang dimiliki oleh penulis tidak memadai untuk dipaparkan sebagai sampel.

Fragmen arca yang ditemukan pada kompleks percandian Batujaya dalam hasil penelitian yang dilakukan oleh Hasan Djafar dibagi dalam empat kategori berdasarkan mediumnya, yaitu arca batu, arca perunggu, arca stuko, dan arca terakota. Fragmen arca batu yang ditemukan hanya berupa pecahan kepala yang berbentuk ikal rambut Budha; sementara fragmen arca perunggu hanya berupa fragmen kaki berukuran kecil sebanyak tiga buah. Kedua tipe fragmen arca ditemukan di situs Segaran V (SEG V atau Unur Blandongan) [1].

Fragmen arca stuko hanya ditemukan di situs TLJ I, tepatnya pada sektor TLJ IC. Ditemukan sekitar 15 buah fragmen arca stuko berbentuk kepala dengan rupa 
manusia atau dewa dan rupa kepala hewan. Tinggi fragmen-fragmen arca tersebut sekitar 10-15 cm. Berdasarkan pertimbangan jumlah data tersebut, sampel fragmen arca yang menggunakan medium stuko menjadi rujukan visual utama dalam penelitian ini.

Selain fragmen arca yang terbuat dari bahan stuko, terdapat satu fragmen arca kepala dari bahan terakota yang kini menjadi bagian dari koleksi Museum Sri Baduga Bandung. Fragmen tersebut memiliki tinggi sekitar $25 \mathrm{~cm}$.

Terdapat ciri khas pada fragmen arca-arca Batujaya, terutama pada aspek profil wajah manusianya. Secara umum, arca-arca tersebut memiliki gaya perupaan naturalistik dengan kecenderungan stilasi dan distorsi pada bentuk wajah yang bulat, hidung pesek dan lebar, bibir tebal, serta mata yang besar. Pada arca-arca hewan, bagian mata umumnya divisualisasikan dengan bentuk yang bulat dan pupil yang menonjol.

Votive tablet atau materai yang terbuat dari terakota yang ditemukan di situs SEG V ditemukan pada lapisan yang diduga merupakan lapisan fase I. Jumlahnya sekitar 10 buah; rata-rata berdimensi $6 \times 4 \times 0,5 \mathrm{~cm}$. Sebagian dari votive tablet tersebut memiliki inskripsi yang diduga menggunakan aksara Pallava di bagian bawahnya. Meskipun votive tablet umum dijumpai pada tempat-tempat suci agama Budha, votive tablet terakota dengan bentuk yang ditemukan di situs Batujaya belum pernah ditemukan di situs-situs lainnya di Indonesia [1].Berikut penjabaran wujud rupa sampel votive tablet Batujaya (Gambar 1):
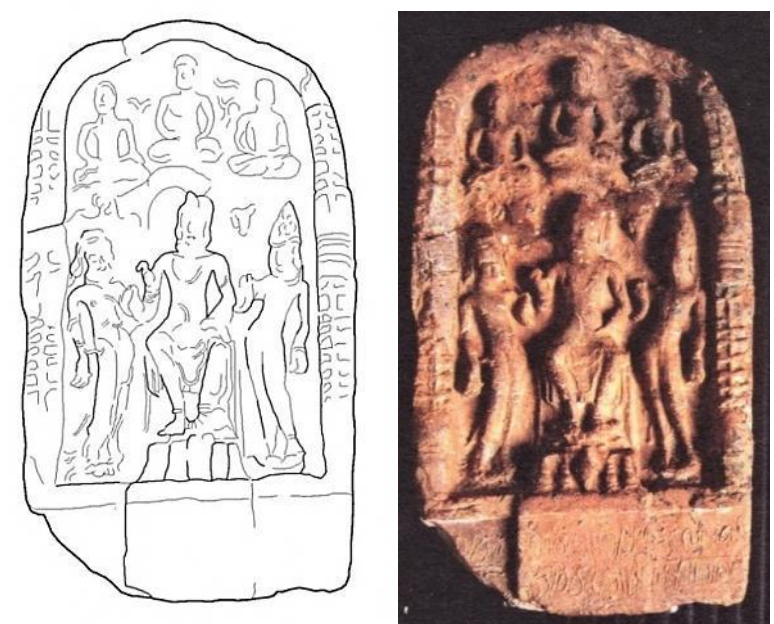

Gambar 1 Votive Tablet Batujaya [1,4]. 
Terdapat dua pembagian pada komposisi perupaan votive tablet Batujaya. Pada bagian atas tampak tiga sosok yang diasumsikan merupakan Budha atau bodhisattva yang duduk bersila dengan gestur dhyana mudra (meditasi). Di bagian bawah terdapat tiga sosok yang divisualisasikan lebih besar. Sosok di tengah yang diperkirakan merupakan bodhisattva berada dalam posisi duduk; tangan kanan terangkat dalam gestur yang diasumsikan sebagai abhaya mudra, sementara tangan kiri diletakkan di atas paha kiri. Detail lipatan kain dan aksesori cukup terlihat. Sosok ini diapit oleh dua bodhisattva yang berdiri dengan pose tribhanga dan salah satu tangan terangkat dalam gestur yang kemungkinan merupakan abhaya mudra [1].

\section{Perbandingan Gaya Perupaan Artefak Percandian Batujaya dengan Seni Rupa Budha Global}

Hasil penelitian-penelitian terdahulu seperti yang telah dilakukan oleh Hasan Djafar [1] Pierre-Yves Manguin dan Agustijanto Indradjaja [2] telah menghasilkan interpretasi tentang adanya dua fase pembangunan kompleks percandian Batujaya: fase I terjadi pada masa sekitar abad ke-6 hingga ke-7 Masehi, ditandai dengan kehadiran Kerajaan Tarumanegara; sementara fase II terjadi antara awal abad ke-8 hingga akhir abad ke-10 Masehi, ditandai dengan keberadaan Kerajaan Sunda.

Inskripsi pada Prasasti Tugu mengenai pembangunan saluran irigasi mengisyaratkan bahwa masyarakat Tarumanegara merupakan komunitas yang hidup dengan bercocok tanam; kemungkinan dengan sistem sawah. Letak kompleks percandian Batujaya yang berada pada DAS (daerah aliran sungai) Citarum memungkinkan adanya persawahan yang memudahkan persediaan logistik bagai masyarakat pembangun kompleks percandian, sementara letaknya yang dekat dengan garis pantai memungkinkan perdagangan dan komunikasi dengan kebudayaan luar Batujaya melalui jalur maritim. Secara sinkronik, posisi Batujaya dalam situasi kebudayaan Budha global dijabarkan pada Tabel 2 di bawah ini.

Menilik Tabel 2, votive tablet dan arca-arca Batujaya sezaman dengan artefakartefak yang memiliki gaya perupaan Gupta (India), Dwarawati (Thailand), dan berada pada masa Klasik Awal seni rupa Indonesia dengan karya seni pada candi Borobudur sebagai pencapaian utamanya. Berdasarkan data-data tersebut, penulis mencoba untuk menafsirkan perupaan pada artefak Batujaya dengan artefak periode Mon-Dwarawati dan artefak Borobudur sebagai perbandingan gaya visual, untuk kemudian dikaji lebih lanjut mengenai pemaknaannya. Kedua sampel tersebut digunakan karena berasal dari periode yang sinkron dengan artefak-artefak Batujaya, yaitu sekitar abad ke-6 hingga ke-10 Masehi. 
Sementara itu, artefak Borobudur dapat digunakan untuk mengkaji evolusi gaya perupaan seni Budha Indonesia melalui perbandingan dengan artefak Batujaya.

Tabel 2 Perbandingan Kronologi Gaya Perupaan.

\begin{tabular}{|c|c|c|c|c|}
\hline Tahun & India & Asia Tenggara & Nusantara & Batujaya \\
\hline $300 \mathrm{SM}$ & & \multirow{3}{*}{\multicolumn{2}{|c|}{ Zaman Neolitik dan Perunggu }} & \\
\hline $200 \mathrm{SM}$ & $\begin{array}{l}\text { Periode } \\
\text { Maurya } \\
\text { (sekitar } \\
322-185 \\
\text { SM) }\end{array}$ & & & $\begin{array}{c}\text { Masa } \\
\text { Prasejarah- }\end{array}$ \\
\hline $100 \mathrm{SM}$ & \multirow{2}{*}{$\begin{array}{c}\text { Periode } \\
\text { Shunga } \\
\text { (sekitar } \\
\text { 185-72 SM) }\end{array}$} & & & $\begin{array}{l}(1000 \mathrm{SM}- \\
500 \mathrm{M})\end{array}$ \\
\hline $\mathbf{0} \mathbf{M}$ & & \multirow[b]{2}{*}{$\begin{array}{c}\text { Tahap Awal (sekitar } \\
\text { abad 1-7 M) }\end{array}$} & \multirow{6}{*}{$\begin{array}{l}\text { Periode Protosejarah } \\
\quad(200-600 \mathrm{M})\end{array}$} & \\
\hline $100 \mathrm{M}$ & Periode & & & \\
\hline $200 \mathrm{M}$ & $\begin{array}{c}\text { Andhra - } \\
\text { Kushan }\end{array}$ & Kamboja: Periode & & \\
\hline $300 \mathrm{M}$ & $\begin{array}{c}(72 \text { SM-320 } \\
\text { M) }\end{array}$ & $\begin{array}{l}\text { Funan dan Zhenla } \\
\text { (abad ke-1 hingga } 9\end{array}$ & & $\begin{array}{l}\text { Masa Peralihan } \\
(60-540 \mathrm{M})\end{array}$ \\
\hline $400 \mathrm{M}$ & \multirow{3}{*}{$\begin{array}{l}\text { Periode } \\
\text { Gupta } \\
(320-647 \\
\text { M) }\end{array}$} & \multirow{3}{*}{$\begin{array}{c}\text { Thailand: Periode } \\
\text { Dwarawati (abad ke-6 } \\
\text { hingga } 10 \mathrm{M})\end{array}$} & & \\
\hline $500 \mathrm{M}$ & & & & Masa Hindu- \\
\hline $600 \mathrm{M}$ & & & \multirow{3}{*}{$\begin{array}{c}\text { Periode Klasik Awal } \\
\quad(600-900 \mathrm{M}): \\
\text { Pembangunan Candi } \\
\text { Borobudur di Jawa } \\
\text { Tengah }\end{array}$} & $\begin{array}{c}\text { Budha } \\
\text { (Fase I: abad }\end{array}$ \\
\hline $700 \mathrm{M}$ & \multirow{4}{*}{$\begin{array}{c}\text { Periode } \\
\text { Pertengahan } \\
\text { (dari abad } \\
\text { ke } 7-19 \mathrm{M})\end{array}$} & \multirow{2}{*}{$\begin{array}{l}\text { Tahap Pertengahan } \\
(\text { sekitar abad } 8-10 \mathrm{M})\end{array}$} & & $\begin{array}{l}\text { ke-6 hingga ke- } \\
7 \text { Masehi) }\end{array}$ \\
\hline $800 \mathrm{M}$ & & & & \\
\hline $900 \mathrm{M}$ & & Nusantara: Srivijaya & & Masa Hindu- \\
\hline $1000 \mathrm{M}$ & & $\begin{array}{l}\text { (abad 7-13); Dinasti } \\
\text { Shailendra } \\
\text { Kamboja: Angkor } \\
\text { (abad 9-15 M) }\end{array}$ & $\begin{array}{c}\text { Periode Klasik } \\
\text { Pertengahan (900- } \\
\text { 1250) }\end{array}$ & $\begin{array}{c}\text { Budha } \\
\text { (Fase II: abad } \\
\text { ke-8 hingga ke- } \\
\text { 10 Masehi) }\end{array}$ \\
\hline
\end{tabular}

Kumpulan votive tablet atau materai yang ditemukan pada kompleks percandian Batujaya berasal dari lapisan fase I, yaitu sekitar abad ke-6 hingga ke-7 Masehi. Artefak serupa merupakan bagian dari kelompok besar votive tablet yang ditemukan di berbagai situs di Asia Tenggara seperti Burma, Thailand dan Champa yang bertanggal sekitar abad ke-6 hingga ke-7 Masehi. Pembuatan votive tablet dari tanah liat yang tidak dibakar di Tibet dan daerah kerajaan 
Sriwijaya sendiri dimulai seiring dengan penyebaran Mahayanisme di daerah tersebut [6].

Materai-materai tersebut umumnya menggambarkan sosok Budha yang duduk di atas singgasana dengan sikap tangan abhaya mudra dan diapit oleh dua sosok yang berdiri dengan sikap tribhanga, tiga sosok Budha dengan posisi duduk di bagian atas, serta sikhara ("puncak gunung" dalam bahasa Sanskerta; biasanya merujuk pada bentuk menara) yang berlapis pada bagian sisinya [2]. Materai tanah liat atau votive tablet memiliki peran penting dalam Budha Mahayana. Dipercaya bahwa jika kelak agama Budha mulai menghilang, orang akan tetap mengingatnya melalui artefak-artefak tersebut [6].

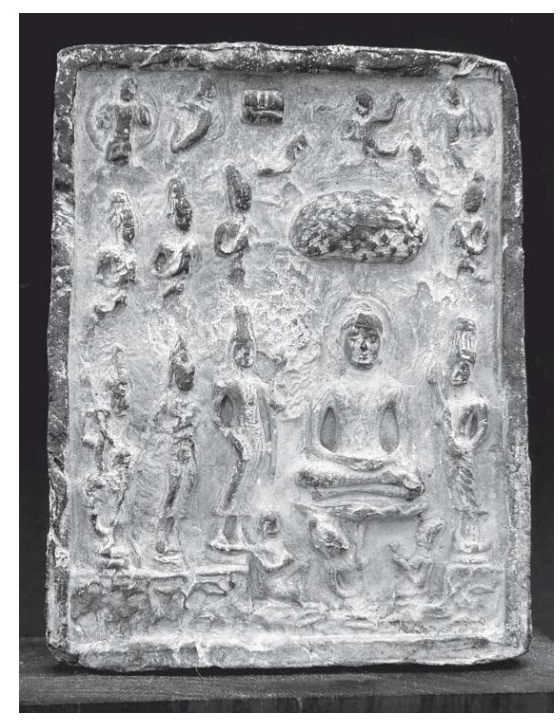

Gambar 2 Budha dengan Pengiring (Votive Tablet, terakota, tinggi $14 \mathrm{~cm}$ ).

Koleksi National Museum, Bangkok, Thailand. [7].

Votive tablet pada Gambar 2 umumnya ditafsirkan sebagai penggambaran adegan Keajaiban Sravasti, meskipun kemudian muncul pendapat-pendapat lain yang menyatakan pemaknaan yang berbeda [7]. Kemiripan antara Gambar 2 dengan votive tablet Batujaya adalah komposisi visual dimana Budha diapit oleh dua figur (kemungkinan bodhisattva) dengan posisi tribhanga dan adanya sosok-sosok lain di bagian atas materai; kedua votive tablet memiliki dua pembagian, yaitu atas dan bawah. Tata ungkapan dengan ukuran pengambilan besar dan sudut pengambilan bawah menyatakan bahwa obyek tersebut dipentingkan [8] dalam hal ini dapat diasumsikan bahwa figur-figur pada bagian bawah kedua votive tablet merupakan bagian utama dari isi votive tablet tersebut. Penjabaran lebih lanjut dapat dilihat pada Tabel 3. 
Tabel 3 Perbandingan Gaya Perupaan Votive Tablet Batujaya dan Mon.

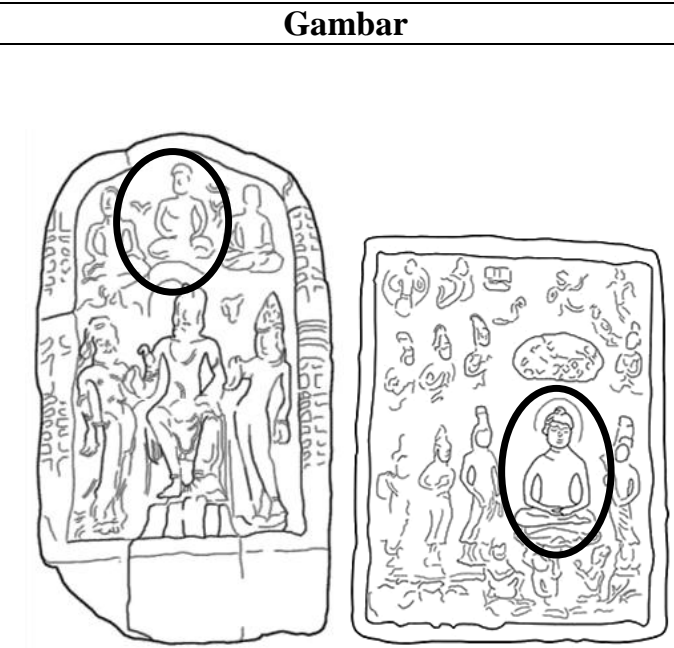

$[\mathbf{A}][\mathbf{B}]$

Votive Tablet Batujaya (A) dan Mon (B) [4]

- Gaya perupaan pada kedua votive tablet adalah naturalis-stilasi; terlihat pada proporsi badan yang natural dengan sedikit stilasi pada bagianbagian tubuh.

- Di bagian yang ditandai dengan lingkaran, terdapat sosok sentral yang diasumsikan merupakan Budha atau Tathagata (istilah yang digunakan Budha untuk merujuk dirinya sendiri, terkadang disebut juga sebagai Dhyani Budha).

- Teridentifikasi melalui atribut pakaian yang sederhana, tidak mengenakan perhiasan seperti bodhisattva, dan adanya usnisa atau gundukan di atas kepala [9].

- Posisi duduk bersila; kemungkinan posisi padmasana (posisi teratai); posisi tangan pada dhyana mudra (gestur meditasi).

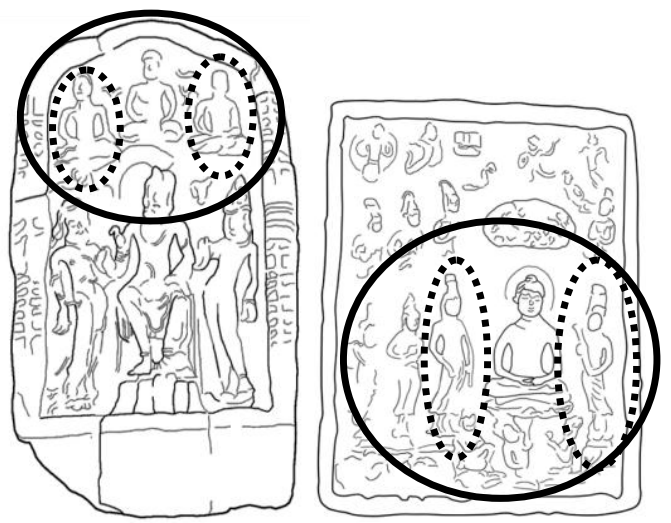

[A] [B]

Votive Tablet Batujaya (A) dan Mon (B) [4]
- Dua figur lain yang mengapit sosok sentral ditampilkan lebih kecil. Dalam teori bahasa rupa, tata ungkapan bagi figur yang penting biasanya ditampilkan lebih besar [8], sehingga besar kemungkinan bahwa figur sentral adalah Budha historis, Sakyamuni, sementara dua sosok yang mengapitnya adalah bodhisattva.

- Meskipun demikian, terdapat perbedaan dimana dua sosok yang mengapit Budha di bagian atas [A] berada dalam posisi padmasana dan konfigurasi ketiganya berada di bagian atas votive tablet, sementarasosok yang mengapit Budha pada [B] berada pada posisi berdiri tribangha dan konfigurasinya berada di bagian bawah votive tablet. 
Tabel 3 (Lanjutan) Perbandingan Gaya Perupaan Votive Tablet Batujaya dan Mon.

\begin{tabular}{|c|c|}
\hline Gambar & Keterangan \\
\hline $\begin{array}{c}\text { Votive Tablet Batujaya (A) } \\
{[4]}\end{array}$ & $\begin{array}{l}\text { - Pada bagian bawah votive tablet terdapat tiga } \\
\text { sosok; dua sosok (lingkaran putus-putus) } \\
\text { berdiri dengan posisi tribhanga dan satu sosok } \\
\text { di tengah (lingkaran) duduk di singgasana } \\
\text { dengan posisi pralambapadasana (posisi } \\
\text { duduk dengan dua kaki terjuntai) dengan } \\
\text { posisi tangan yang diasumsikan adalah } \\
\text { abhaya mudra (gestur tolak bala). } \\
\text { - Konfigurasi Budha yang duduk di singgasana } \\
\text { dan diapit dua bodhisattva banyak didapati di } \\
\text { kawasan Asia Tenggara [2]. } \\
\text { - Ikonografi untuk sosok Budha umumnya tidak } \\
\text { menggambarkan aksesoris karena Budha telah } \\
\text { meninggalkan hal-hal duniawi, sementara } \\
\text { bodhisattva sebagai calon Budha biasanya } \\
\text { memiliki aksesori untuk menggambarkan } \\
\text { bahwa ia masih terkait dengan dunia meski } \\
\text { telah mengalami Pencerahan. } \\
\text { - Berdasarkan hal ini, kemungkinan tiga sosok } \\
\text { pada votive tablet Batujaya lebih mengacu } \\
\text { pada salah satu pantheon bodhisattva. Sosok } \\
\text { di tengah kemungkinan adalah } \\
\text { Avalokitesvara, bodhisattva yang paling } \\
\text { banyak dijumpai di Asia Tenggara. }\end{array}$ \\
\hline
\end{tabular}

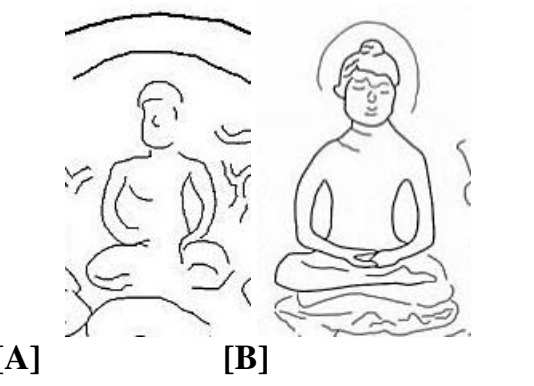

Votive Tablet Batujaya (A) dan Mon (B) [4]
- Meskipun terdapat perbedaan komposisi, terdapat kemiripan antara visualisasi pada votive tablet Batujaya dengan votive tablet Mon.

- Sosok yang diinterpretasikan sebagai Budha Sakyamuni atau Tathagata ditampilkan dengan garis kurva yang luwes dan halus, terutama pada bagian bahu-lengan dan lipatan lutut, dan dada bidang dengan pinggang langsing. 
Tabel 3 (Lanjutan) Perbandingan Gaya Perupaan Votive Tablet Batujaya dan Mon.

\begin{tabular}{|c|c|}
\hline Gambar & Keterangan \\
\hline $\begin{array}{c}{[\mathrm{C}]} \\
\text { Votive Tablet Batujaya (A) dan Mon } \\
\text { (B); Patung Budha Periode Gupta } \\
\text { (C) }[1,7,10]\end{array}$ & $\begin{array}{l}\text { - Merujuk kembali pada Tabel 3, Fase I } \\
\text { Batujaya dan periode Mon-Dwarawati } \\
\text { bersilangan dengan periode Gupta di } \\
\text { India. } \\
\text { - Sebagai bahan komparasi visual yang } \\
\text { lebih detail, perhatikan outline sosok } \\
\text { Budha periode Gupta pada Gambar [C]: } \\
\text { garis kurva yang luwes, dada bidang } \\
\text { dan pinggang langsing seperti pada } \\
\text { Gambar [A] dan [B]. } \\
\text { - Dapat diasumsikan bahwa kawasan } \\
\text { kerajaan Dwarawati dan Batujaya } \\
\text { mendapat pengaruh gaya perupaan } \\
\text { Gupta yang sezaman, sehingga terdapat } \\
\text { kemiripan dalam kecenderungan visual } \\
\text { yang diterapkan oleh masing-masing. }\end{array}$ \\
\hline
\end{tabular}

Penelitian terdahulu yang dilakukan oleh P.E.J Ferdinandus pada tahun 1998 [1] menghasilkan tafsiran bahwa perupaan votive tablet Batujaya merujuk pada adegan Keajaiban Sravasti. Meskipun demikian, pendapat ini kemudian dibantah Hariani Santiko dalam tulisannya yang berjudul Perkembangan Awal Agama-agama di Indonesia tahun 2003 yang berpendapat bahwa votive tablet Batujaya belum tentu menggambarkan adegan Keajaiban Sravasti. Visualisasinya dianggap lebih mirip dengan tokoh-tokoh Tara (bodhisattva perempuan sebagai pendamping bodhisattva pria) yang terdapat pada votive tablet Borobudur [1]. Penjabaran lebih lanjut dapat dilihat pada Tabel 4.

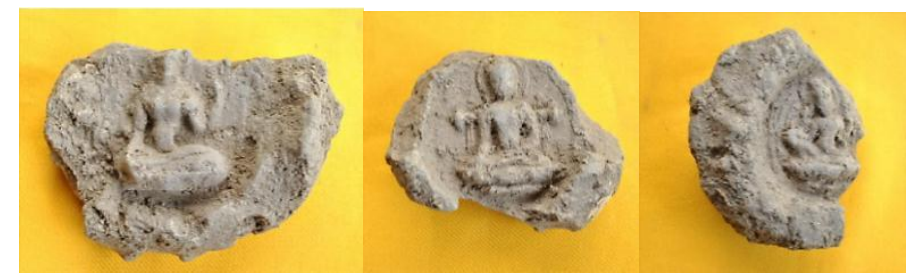

Gambar 3 Votive Tablet Borobudur. [11] 
Tabel 4 Perbandingan Gaya Perupaan Votive Tablet Batujaya dan Borobudur.

Keterangan
$\begin{aligned} & \text { Votive tablet Borobudur yang } \\ & \text { menggambarkan Dewi Tara (lihat } \\ & \text { Gambar 3) berbentuk bulat; tidak } \\ & \text { seperti votive tablet Batujaya yang } \\ & \text { persegi panjang. } \\ & \text { Penelitian terdahulu menyatakan } \\ & \text { bahwa visualisasi votive tablet } \\ & \text { Batujaya diangap mirip dengan } \\ & \text { tokoh Tara yang terdapat pada } \\ & \text { votive tablet Borobudur [1]. } \\ & \text { Asumsi ini kemungkinan diperoleh } \\ & \text { melalui tampilan siluet yang } \\ & \text { terlihat langsing dan luwes. }\end{aligned}$

Penelitian terdahulu [2] menyatakan kecenderungan perupaan ornamen kompleks percandian Batujaya yang berupa relief tinggi menggunakan bahan stuko mengingatkan pada candi-candi periode Dwarawati di Thailand, dimana denah Candi Blandongan atau situs SEG V sendiri lebih mirip dengan denah candi periode Dwarawati seperti Wat Phra Men di Nakhon Phatom. Argumen ini menghasilkan interpretasi bahwa artefak-artefak Batujaya, jika ia memang sezaman dengan candi-candi Dwarawati tersebut (sekitar abad ke-6 atau ke-7 Masehi), berasal dari lapisan di Fase I.

Dua bangunan periode Dwarawati yang tertua adalah stupa 40 di Khu Bua, dan stupa Chunla Pathon yang terletak di kota Dwarawati terbesar, Nakhon Pathom. Arca kepala terakota dari Khu Bua (Gambar 4A) diperkirakan merupakan 
representasi Bodhisattva, dan kemungkinan merupakan bagian dari figur lengkap [7]. Pada situs Batujaya juga ditemukan satu fragmen kepala arca terakota dengan tinggi sekitar $25 \mathrm{~cm}$ yang disimpan di Museum Sri Baduga, Bandung (Tabel 1, Gambar 2). Baik arca Khu Bua dan arca Batujaya memiliki kemiripan dalam visualisasi profil wajah: mata yang tertutup, hidung besar dan terlihat pesek, serta bibir agak tebal yang tersenyum. Terdapat sedikit perbedaan dimana profil arca Batujaya terlihat lebih datar dengan bentuk wajah lebih bulat dan hidung lebih besar. Terdapat kemungkinan profil wajah kedua jenis arca didasarkan pada jenis wajah masyarakat lokal, meskipun ada pula kemungkinan profil wajah tersebut merupakan hasil adaptasi dari India.

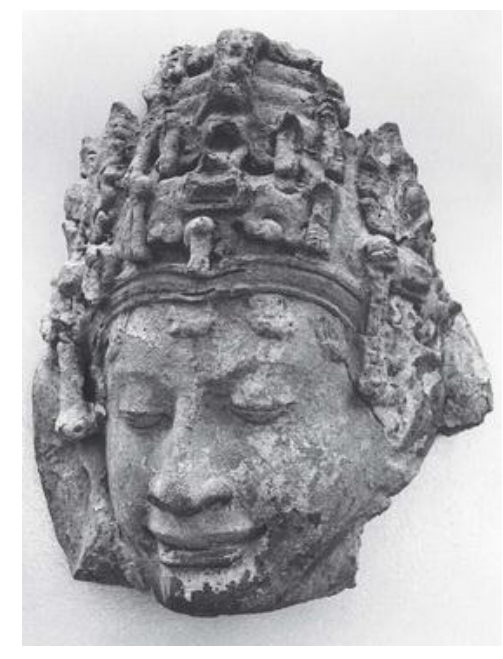

[A]

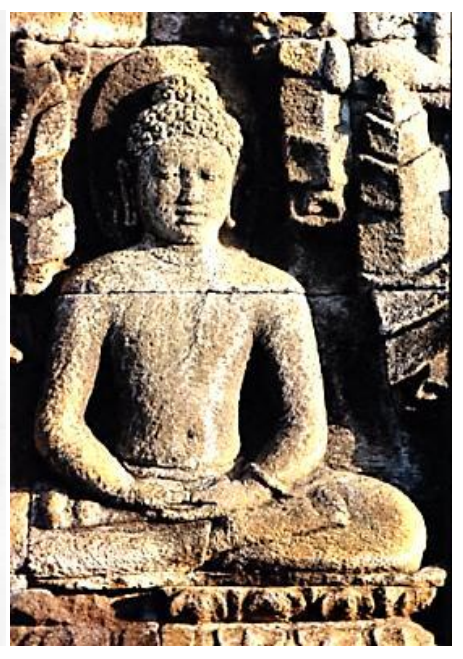

[B]

Gambar 4 Arca Kepala (A) Terakota, Khu Bua, Periode Dwarawati dan Arca Budha Sakyamuni, Borobudur (B). [7,12]

Arca Budha Sakyamuni (Gambar 4B) yang terdapat di Borobudur berasal dari masa yang lebih muda dibandingkan arca Batujaya maupun Mon-Dwarawati. Meskipun demikian, terdapat asumsi yang menyatakan bahwa seni rupa Budha di Jawa memiliki gaya perupaan yang hampir serupa dengan seni Budha dari India bagian timur laut yang berasal dari masa pemerintahan dinasti Gupta dan Pala, misalnya Sarnath dan Nalanda [13], sama halnya dengan gaya perupaan Batujaya dan Mon-Dwarawati yang telah dibahas sebelumnya. Berdasarkan pertimbangan tersebut, sampel arca Borobudur pada Gambar 4B dapat dijadikan bahan perbandingan gaya perupaan dengan arca Batujaya. 
Tabel 5 Perbandingan Gaya Perupaan Arca Kepala Batujaya, Mon dan Borobudur.
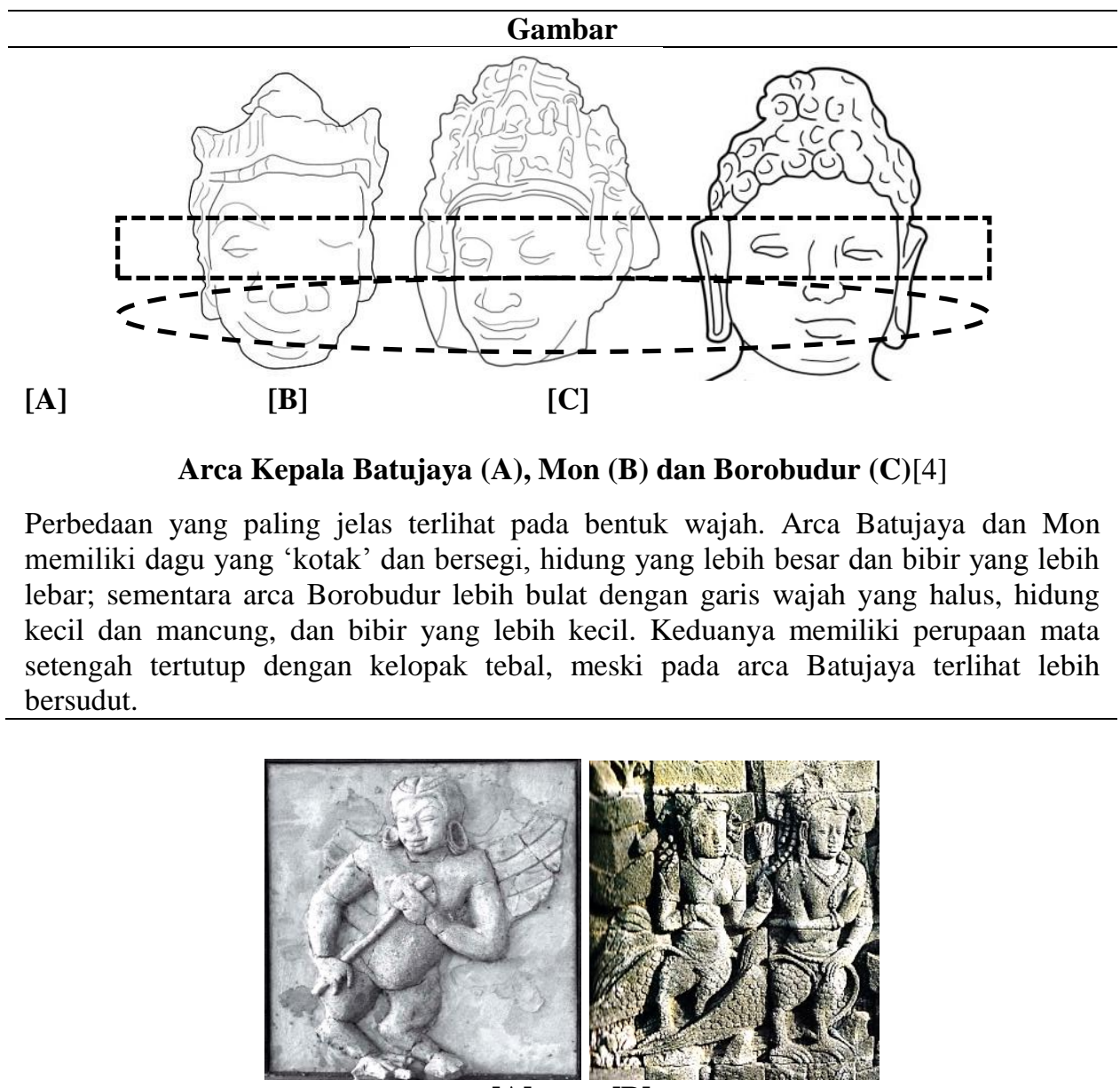

[A]

[B]

Gambar 5 Kinnara (Relief Stuko) Nakhon Pathom [A] dan Borobudur [B]. $[7,13]$.

Beberapa jenis ornamen stuko yang didapati pada kompleks percandian Batujaya merupakan arca-arca kepala. Arca-arca tersebut tidak sepenuhnya tiga dimensional; kemungkinan merupakan bagian dari relief tinggi yang menghiasi dinding percandian. Pada stupa Chunla Pathon di Nakhon Pathom terdapat pula relief tinggi dari stuko, contohnya berbentuk kinnara (mahluk legenda setengah burung) seperti pada Gambar 5. Beberapa penelitian terdahulu telah menghasilkan asumsi bahwa arca-arca stuko Batujaya menggambarkan tokoh manusia atau mahluk kedewataan [1]. Meskipun demikian, arca stuko Batujaya tidak memiliki atribut selengkap stuko Chunla Pathon, sehingga tidak dapat 
dikatakan bahwa stuko Batujaya juga merupakan kinnara. Sebagai bahan perbandingan, akan digunakan visualisasi kinnara dari salah satu bagian dari relief Gandavyuha yang terdapat di Borobudur.

Tabel 6 Perbandingan Gaya Perupaan Arca Batujaya dengan Mon dan Borobudur.

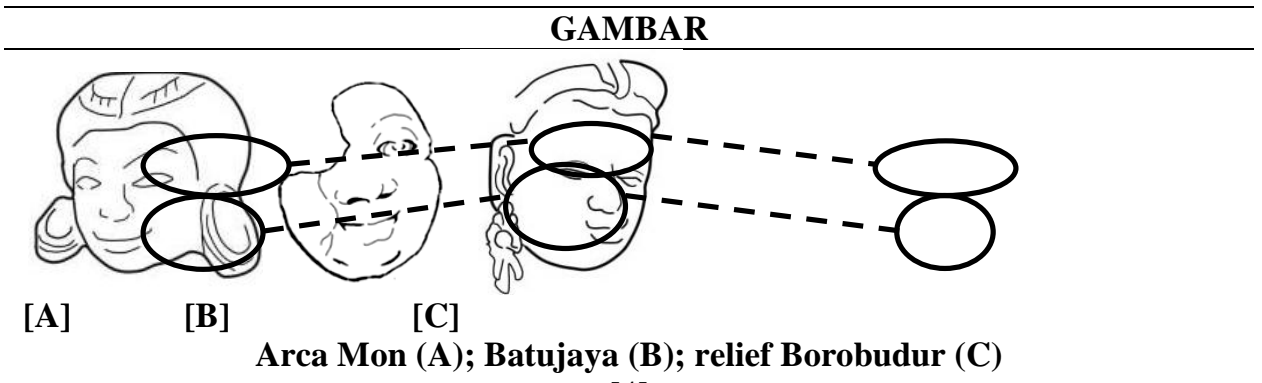

[4]

Ketiga sampel memiliki perupaan mata setengah tertutup. Pada sampel Batujaya dan Borobudur kelopak mata terlihat dan tebal, sementara pada sampel Mon kelopak tidak jelas terlihat. Pada bagian hidung, sampel Batujaya memiliki bentuk hidung yang besar dan pesek, sementara Mon dan Borobudur lebih kecil. Hidung pada sampel Borobudur divisualisasikan lebih mancung dibandingkan Batujaya dan Mon. Pada bagian bibir, baik Batujaya dan Mon terlihat lebih lebar dari Borobudur; meski Mon terlihat lebih tipis dari yang lain.

Dari beberapa contoh perbandingan di Tabel 6, terlihat bahwa perupaan pada votive tablet dan arca Batujaya lebih cenderung memiliki kesamaan dengan artefak-artefak Chunla Pathon dan Khu Bua, terutama dari komposisi visual pada votive tablet dan profil wajah pada arca. Komparasi dengan artefak Borobudur menunjukkan adanya perbedaan profil wajah yang cukup jelas terlihat pada perupaan arca, meskipun masih terdapat kesamaan pada outline obyek yang terlihat luwes dan langsing pada votive tablet. Jika ditilik secara kronologis, baik Batujaya (abad ke-6 hingga ke-10 Masehi), Borobudur (era Klasik Awal; sekitar abad ke-8 hingga ke-10 Masehi), Chunla Pathon dan Khu Bua (periode Dwarawati; abad ke-6 hingga ke-10 Masehi) berada pada masa yang saling berdekatan. Secara geografis, jarak antara Batujaya dan Borobudur yang berada di satu pulau jauh lebih dekat dibandingkan dengan pusat kebudayaan Mon-Dwarawati di Asia Tenggara daratan. Berdasarkan argumen tersebut, kemungkinan persamaan gaya perupaan antara Batujaya dan Borobudur seharusnya lebih dekat dibandingkan dengan artefak MonDwarawati.

Menurut J.G de Casparis, Borobudur mulai dibangun sekitar tahun 824 Masehi berdasarkan prasasti Kayumwungan (Karang Tengah) yang berisikan peringatan 
pembangunan candi Borobudur oleh Samaratungga dan Pramordawardhani [11]. Asumsi tersebut menandakan bahwa secara kronologis candi Borobudur berada pada periode yang lebih dekat dengan Fase II Batujaya (abad ke-8 hingga ke-10 Masehi). Sejauh ini penanggalan artefak-artefak Batujaya sendiri belum dapat diperkirakan; jika diasumsikan bahwa artefak yang menjadi sampel penelitian ini berasal dari Fase I (abad ke-6 hingga ke-7 Masehi), maka renggang waktu antara Borobudur dan Batujaya tersebut kemungkinan merupakan faktor penyebab perbedaan gaya perupaan. Selain itu faktor lain seperti hubungan politik antar kerajaan kemungkinan turut mempengaruhi kecenderungan perupaan, meskipun asumsi tersebut harus dielaborasi lebih lanjut.

Ketiga gaya perupaan cenderung bersifat naturalis-stilasi; tetapi ciri khas pada artefak Batujaya terutama arca terlihat pada bentuk mata yang cenderung didistorsi menjadi lebih besar dan terkesan membelalak, serta hidung yang lebar. Terdapat beberapa kemungkinan akan kecenderungan ini; masyarakat pendukung kebudayaan Batujaya memiliki bentuk fisik sedemikian dibandingkan masyarakat pendukung kebudayaan Mon-Dwarawati dan Borobudur, atau visualisasi demikian merupakan pemikiran masyarakat pendukung kebudayaan Batujaya mengenai wajah atau fisik yang ideal sehingga akhirnya mereka terapkan pada perupaan arca-arca Batujaya.

\section{Kesimpulan}

Keberadaan sejumlah votive tablet pada kompleks percandian dengan perupaan yang menggambarkan sosok-sosok bodhisattva dan Budha mengindikasikan keberadaan mazhab Mahayana pada kompleks percandian Batujaya. Adanya kemiripan gaya visual dengan votive tablet periode Mon-Dwarawati abad ke-7 dan votive tablet Borobudur abad ke-8 menunjukkan adanya gaya 'internasional' Asia Tenggara. Meskipun demikian, komposisi visual pada votive tablet Batujaya dan Mon-Dwarawati lebih kompleks dengan pembagian atas dan bawah, sementara votive tablet Borobudur hanya memiliki satu figur sentral.

Arca-arca stuko dan terakota Batujaya juga memiliki kemiripan, terutama dalam segi profil wajah, dengan arca-arca stuko dan terakota Khu Bua dan Nakhon Pathom pada periode Dwarawati. Terdapat dua kemungkinan akan hal ini: profil wajah tersebut berdasarkan gaya India sehingga memiliki gaya perupaan yang mirip, atau profil wajah masing-masing menggunakan tipe masyarakat lokal Asia Tenggara yang tidak jauh berbeda. Arca Batujaya cenderung memiliki bentuk mata yang didistorsi menjadi lebih besar dan terkesan membelalak, serta hidung yang lebar. Kecenderungan ini kemungkinan dikarenakan masyarakat pendukung kebudayaan Batujaya memiliki bentuk fisik sedemikian 
dibandingkan masyarakat pendukung kebudayaan Mon-Dwarawati dan Borobudur, atau visualisasi demikian merupakan pemikiran masyarakat pendukung kebudayaan Batujaya mengenai wajah atau fisik yang ideal sehingga akhirnya mereka terapkan pada perupaan arca-arca Batujaya.

Terdapat perbedaan yang cukup signifikan antara artefak Batujaya dengan Borobudur meskipun keduanya berasal dari periode yang berdekatan, yaitu abad ke-6 hingga ke-10 Masehi (Batujaya) dan abad ke-8 hingga ke-10 Masehi (Borobudur), serta jarak antara Batujaya dan Borobudur yang berada di satu pulau yang jauh lebih dekat dibandingkan dengan pusat kebudayaan MonDwarawati di Asia Tenggara daratan. Komparasi dengan artefak Borobudur menunjukkan adanya perbedaan profil wajah yang cukup jelas terlihat pada perupaan arca, meskipun masih terdapat kesamaan pada outline obyek yang terlihat luwes dan langsing pada votive tablet. Jika diasumsikan bahwa artefak yang menjadi sampel penelitian berasal dari Fase I, yaitu abad ke-6 hingga ke-7 Masehi, maka renggang waktu antara Borobudur dan Batujaya tersebut kemungkinan merupakan faktor penyebab perbedaan gaya perupaan.

Faktor lain seperti hubungan politik antar kerajaan kemungkinan turut mempengaruhi kecenderungan perupaan; asumsi ini dapat dielaborasi oleh penelitian-penelitian selanjutnya. Sampel artefak yang lebih beragam diperlukan bagi penelitian selanjutnya sehingga dapat diperoleh data perbandingan gaya visual yang lebih akurat.

\section{Referensi}

[1] Djafar, H. 2010. Kompleks Percandian Batujaya, Bandung: Kiblat Buku Utama.

[2] Manguin, P-Y., Mani, A. \& Wade, G. (ed). 2011. Early Interactions Between South and Southeast Asia: Reflections on Cross-Cultural Exchange, Singapore: Institute of Southeast Asian Studies.

[3] Koentjaraningrat. 2005. Pengantar Antropologi, I, Jakarta: PT Rineka Citra.

[4] Ramadina, S.P. 2012. Analisis Perupaan dan Sinkronisasi Arca dan Votive Tablet Percandian Batujaya di Karawang, Jawa Barat dengan Borobudur di Jawa Tengah dan Mon-Dwarawati di Thailand, Tesis Magister, Bandung: Fakultas Seni Rupa dan Desain Institut Teknologi Bandung.

[5] Puslit Arkenas. 2004. Database Foto Percandian Batujaya, Jakarta: Pusat Penelitian Arkeologi Nasional, 2004.

[6] Jermsawatdi, P. 1979. Thai Art with Indian Influences, New Delhi: Abhinav Publishing. 
[7] Woodward, H. 2005. The Art and Architecture of Thailand, Leiden: Koninklijke Brill.

[8] Tabrani, P. 2009. Bahasa Rupa, Bandung: Penerbit Kelir.

[9] Sedyawati, E. 2010. Budaya Indonesia: Kajian Arkeologi, Seni, dan Sejarah, Jakarta: PT. Rajagrafindo Persada.

[10] Honour, H. \& John F. 1995. A World History of Art, London: Laurence King Publishing.

[11] Indradjaya, A. 2011. Stupika dan Votive Tablet Borobudur, Jurnal Konservasi Benda Cagar Budaya: Borobudur, V(5).

[12] Schoppert, P. (ed). 1990. Borobudur: Prayer in Stone, Singapore: Archipelago Press.

[13] Holt, C. 2000. Melacak Jejak Perkembangan Seni di Indonesia, Bandung: Arti Line. 